Milošević, J., \& Risku, H. (2020). Situated cognition and the ethnographic study of translation processes: Translation scholars as outsiders, consultants and passionate participants. Linguistica Antverpiensia, New Series: Themes in Translation Studies, 19, 111-131.

\title{
Situated cognition and the ethnographic study of translation processes: Translation scholars as outsiders, consultants and passionate participants
}

\author{
Jelena Milošević \\ University of Vienna, Austria \\ jelena.milosevic@univie.ac.at \\ https://orcid.org/0000-0003-3404-3845 \\ Hanna Risku \\ University of Vienna, Austria \\ hanna.risku@univie.ac.at \\ https://orcid.org/0000-0003-2165-6669
}

\begin{abstract}
Whereas traditional methods of translation process research aim predominantly at fulfilling the requirements for controlled scientific experiments, shifts towards embodiment and situatedness at a conceptual level require methodological innovations for the analysis of cognitive processes as embedded in their relevant environments. In this article, we concentrate on one of the main challenges in the ethnographic study of translation processes in the translation workplace: the relationship between the researchers and the participants. Drawing on data from a multiple case study, we investigate the perceived role of the researchers and the mutual expectations of both the observers and the observed. In doing so, we examine the attitudes of translators and translation project managers towards researchers in a series of different work settings. Our results indicate that the enquirer posture imposed on the researchers by some participants corresponds with the formers' planned methodological and epistemological approaches, as do their expected trade-offs. Others, in turn, differ substantially from the researchers in their expectations. Based on our own experience and subsequent reflections, we argue that fostering connections between translation scholars and practitioners may contribute to overcoming some of the methodological challenges of ethnographic research in Translation Studies.
\end{abstract}

Keywords: ethnography; enquirer posture; situated cognition; translation process research; workplace research 
Milošević, J., \& Risku, H. (2020). Situated cognition and the ethnographic study of translation processes: Translation scholars as outsiders, consultants and passionate participants. Linguistica Antverpiensia, New Series: Themes in Translation Studies, 19, 111-131.

\section{Introduction}

In recent decades, different cognitive approaches to translation have required various methods to be applied and developed further in order to study translation processes. While traditional translation process research methods aim predominantly at fulfilling the requirements for controlled scientific experiments (see e.g., Jakobsen, 2017), shifts towards embodiment and situatedness at a conceptual level necessitate methodological innovations that allow us to analyse cognitive processes that are embedded in their relevant environments (see e.g., Ehrensberger-Dow \& Hunziker Heeb, 2016; Muñoz Martín, 2010; 2017; Risku, 2017; Risku \& Windhager, 2015). In line with the establishment of the situated and embodied perspectives in Translation Studies, the field of ethnographic and workplace studies seems to be gradually developing into a coherent new sub-sector of translation research. To better understand how translation is viewed, practised and managed outside the academic context, it is now increasingly being studied in authentic workplace settings. Although research of this kind has only recently begun to receive greater attention, first empirical studies are already combining socio-cognitive (e.g., Risku, 2014), ergonomic (e.g., Ehrensberger-Dow \& Massey, 2019), practice-oriented (e.g., Olohan, 2019), affective (e.g., Koskinen, 2008) and other approaches (for recent overviews, see Risku et al., 2019; 2020). In many cases, the aim of these studies is to expand the research focus from exploring exclusively mental, internal or linguistic processes to also including situated, socially, historically and locally embedded interactions.

This shift has been particularly evident in cognitive studies of translation and interpreting. Halverson and Muñoz Martín (2020), for instance, note that "CTIS [Cognitive Translation and Interpreting Studies] researchers are now focusing on all agents, factors, [and] aspects of translation events" (see also Muñoz Martín, 2016). Some of this research is being carried out using ethnographic methods in authentic contexts of action. So what, we ask, motivates CTIS researchers to add the study of the contingencies of uncontrolled real-life translation situations to their theoretical and methodological toolkits? One of their main reasons for doing so stems from developments in the understanding of cognition. In mainstream cognitive science, cognition is often seen as the mental representation and processing of the information that lies between perceiving and acting.

In recent decades, however, a view of cognition has emerged which emphasizes the embeddedness of cognitive processes in their environments and reconceptualizes them as interaction processes that involve the mind, the body and the world (see e.g., Clark, 1996; Suchman, 2007; Walter, 2014). This view includes several approaches that emphasize the roles of the body (embodied cognition), environmental structures and tools (embedded cognition, extended cognition), social processes (distributed cognition), interaction (enactive cognition) or affect. They are frequently referred to collectively as $4 E A$ cognition, second-generation cognitive science, socio-cognitive or simply situated cognition. Walter (2014) discusses four central insights which unify the different situated approaches to cognition and show how and why cognitive science has turned to studying larger units than the internal mental processes in the brain: 
Milošević, J., \& Risku, H. (2020). Situated cognition and the ethnographic study of translation processes: Translation scholars as outsiders, consultants and passionate participants. Linguistica Antverpiensia, New Series: Themes in Translation Studies, 19, 111-131.

(1) In situated approaches, cognition does not take place removed from the body and the environment but instead encompasses continual, reciprocal interaction cycles of perceiving and acting with the environment (see also Clark, 1996 Thelen \& Smith, 1994).

(2) "Abstract" problems such as plans and games of chess move into the background and attention focuses on the challenges to be mastered in the here and now between bodily systems and their environment (see also Suchman, 2007, referring to Agre \& Chapman, 1991).

(3) The body is no longer seen as an input and output vehicle that must be controlled and coordinated but as a valuable cognitive resource in its own right (see also e.g., Clark, 1996; Shapiro, 2019; Wilson, 2002).

(4) The environment is not seen simply as the site of the "problem" but as quite the opposite, namely a resource that can contribute to efficient solutions (also Suchman, 2007, see p. 125 on the concept of "situation").

Cognitive systems therefore keep their internal cognitive effort as low as possible by accessing resources held ready in the world itself. The fact that the situative approaches do not view the role of the internal representation of the environment as decisive for explaining cognition should also be understood in this sense. As Brooks (1991) famously notes: "the world is its own best model" (p. 583).

Whereas classic or mainstream research on the translation process leans heavily on a computational paradigm of cognition (Muñoz Martín, 2017), the situated, non-computational approach to cognition needs to capture the processes by which translators access environmental, situational resources and integrate them into their cognitive processes. Although this can in theory be done either in a laboratory or in a field setting, there is an increasing call for more studies of translation processes in their authentic environments (see, e.g., Angelone, Ehrensberger-Dow, \& Massey, 2016; Christensen, 2011; Hubscher-Davidson, 2011; Sun, 2014) in order to increase the ecological validity of translation process studies and therefore their relevance to real-life translation and translation as work.

To observe and describe translation processes and their underlying cognitive processes in line with the situated notions of cognition, we conducted a qualitative, ethnographic study at several translation workplaces. Studies of this kind become relevant when the researchers seek to obtain both the insider perspective of translation practitioners in the field and an insight into their work environments. As Hubscher-Davidson $(2011$, p. 8) points out, hearing the voices of translators themselves and gaining insights into their perspectives, emotions and views helps us better understand the process of translation. Giving the participants the opportunity to reflect on their work processes and interactions and spending several weeks observing them at their actual workplaces provides ethnographers with a deeper understanding of the interplay between translation processes and their authentic environments than they would be able to gain using mainstream research methods to investigate cognitive translation processes such as thinkingaloud-protocols, keystroke logging, or screen and eye-tracking in the laboratory. 
Milošević, J., \& Risku, H. (2020). Situated cognition and the ethnographic study of translation processes: Translation scholars as outsiders, consultants and passionate participants. Linguistica Antverpiensia, New Series: Themes in Translation Studies, 19, 111-131.

Examples of the use of the ethnographic approach in translation and interpreting studies, including research extraneous to the translation process, include:

- Flynn (2004) on the relevance of the Skopos theory in literary translation;

- Mullamaa (2006) on liaison interpreting;

- Buzelin $(2006,2007)$ on publisher/translator networks;

- Hakola (2007) on the translation of musicals;

- Koskinen (2008) on institutional translation;

- Kastberg (2009) on technical documentation;

- Kuznik and Verd (2010) on the work content of translators;

- Kinnunen (2010) on court interpreting;

- Kolb (2011) and Borg (2017) on literary translation processes;

- Abdallah (2011) on translators in translation production networks;

- Asare (2011) and LeBlanc (2013) on the use of translation technology;

- Massey and Ehrensberger-Dow (2011) and Ehrensberger-Dow (2014) on education and ergonomic needs;

- Marinetti and Rose (2013) on theater translation;

- Hokkanen (2013) on interpreting in religious contexts;

- Risku (2014) on freelance translation;

- Risku (2016) on translation project management;

- Duflou (2016) on becoming a simultaneous interpreter; and

- Olohan and Davitti (2017) on workplace practices in translation companies (for an overview, see Risku 2017; for application contexts in translation and interpreting research, see also Risku et al., 2019).

The multiple case study referred to in this article included interviews and observation sessions in four different translation settings (see Section 3 for a detailed description): a translation agency, a translation department in a public-service institution, two (cooperating) freelance translators and a technology company with its preferred translation agency. Drawing on data from this study, the article considers the possible challenges that researchers might face when encountering the field of translation practice and interacting with practitioners as study participants.

To set the scene, we begin by providing a description of the methodological nature and scope of our research. We then go on to describe and compare the researchers' intended and the participants' perceived enquirer posture and also their mutual expectations and desired tradeoffs. Therefore, the aim of this article is purely methodological in nature: it does not seek to provide information about the translators' actual processes, tools and workflows (this was the objective of the overall study) but instead investigates the perceived role of the researchers, the relationship between the researchers and the participants, and the mutual expectations of the observers and the observed. Accordingly, it seeks to provide insights into the attitudes of the participants towards the researchers in different translation-related work settings, their 
Milošević, J., \& Risku, H. (2020). Situated cognition and the ethnographic study of translation processes: Translation scholars as outsiders, consultants and passionate participants. Linguistica Antverpiensia, New Series: Themes in Translation Studies, 19, 111-131.

reactions to the proposed participation-based approach, the enquirer posture they imposed on the researchers and their expected trade-offs.

\section{Ethnographic workplace research: Where researchers meet practice}

\subsection{Interacting with and in the field}

The study of larger behavioural units in their natural environments is typical of qualitative, ethnographic research, which facilitates learning and understanding of the (cultural) practices in the field under study by looking at the everyday (working) lives of individuals or/and groups (see e.g., Flick, 2017; Meyer, 2013; Robben \& Sluka, 2015). Such investigations are frequently conducted using the participant observation method, where the observers are present and involved in the situation under observation, communicate with the persons observed, perhaps even participate in their activities to some extent, and write field notes as documentation and (self-)reflection in-situ (see e.g., Emerson et al., 2007; Fetterman, 2010). ${ }^{1}$

These field notes are often complemented by research diaries and individual or joint (in the case of research teams) reflection and analysis sessions (see e.g., Emerson et al., 1995; Eriksson et al., 2012). This enables ethnographers to document and discuss their own experiences with the research in detail and incorporate their reflections on their own role, their interaction with the field and their impact on the situations observed into their findings. The data collected through observation are usually complemented by data obtained in interviews with the relevant social actors. The interviews serve to find out more about their views, how they make sense of what is happening in the field and the meaning they attach to both their actions and their environments (see e.g., Flick, 2017).

The researchers' involvement in the field enables them to gain a better understanding of its structures and dynamics. In workplace studies (for a specific approach to workplace research, see e.g., Heath, Knoblauch \& Luff, 2000; Knoblauch \& Heath, 2006), which also draw on observations and/or video recordings and conversation analysis, additional focus is placed on the technological systems used in the targeted work activities. Such studies therefore also examine the interplay between technology and its host environment as well as its influence on the work processes and the actors involved (for more information on ethnographies of work, see also, e.g., Brannan et al., 2007, or Smith, 2007; and on researching translation and interpreting related workplaces, see Risku et al., 2020). Accordingly, we also accorded special attention to this interplay of work processes, technology and environment in our project.

To be able to immerse themselves in the environment they are studying, researchers first have to access the field by explaining the nature and aim(s) of their research to potential study participants and awakening their interest in participating. Good relationships with the field and mutual trust between researchers and participants are likewise essential since the data collection "relies on personal interaction or engagement between the researcher and those being researched in the 
Milošević, J., \& Risku, H. (2020). Situated cognition and the ethnographic study of translation processes: Translation scholars as outsiders, consultants and passionate participants. Linguistica Antverpiensia, New Series: Themes in Translation Studies, 19, 111-131.

research setting" (Pole \& Hillyard 2016, p. 3). Indeed, Pole and Hillyard (2016) consider the position of the researchers to be a key aspect in successful ethnographic research, alongside their management of relationships in the field throughout the research project and their good ethical conduct (a prerequisite for all (successful) interaction with (potential) participants). In other words, ethnographers must pay special attention to their degree of involvement - from the initial consideration and establishment of contact with potential study participants through to the communication of the research results back to those who actually participate.

While managing the ethical aspects of ethnographic studies is a comprehensive topic that would exceed the scope of this article, it nonetheless does need to be mentioned, if only briefly. Good ethical conduct adheres to high ethical research standards which provide orientation and guidance for researchers throughout the research process and their subsequent work with the data. Above all, these standards focus on the ways in which researchers approach and treat their objects of study and handle the data acquired. Providing potential participants with detailed and honest information about the research goals is a crucial element of good ethical conduct, since it will ultimately determine their reaction to the research proposal. Avoiding any possible harm that could arise from participating in the study is a further key element; and it can be achieved, for instance, through anonymizing data and assuring confidentiality (see e.g., Delamont \& Atkinson, 2018; Iphofen, 2013; Murphy \& Dingwall, 2007; Pole \& Hillyard, 2016; ethical aspects of ethnographic research are also discussed in more detail in Risku, 2017; Risku et al., forthcoming).

Since they are often confronted with participants with different and potentially conflicting expectations, the multiple roles that ethnographers assume or are perceived to have assumed can lead to role conflicts (Simmons, 2007) and moral dilemmas (Fine, 2010). Accordingly, there is a strong need for reflection on and a balancing of the proximity between ethnographers and the social situations and actors they are investigating. The level of immersion in the field should allow ethnographers to grasp its inner dynamics and the perspectives of the agents under study. At the same time, ethnographic research requires researchers to distance themselves from their own prior expectations, academic knowledge or practical know-how of the field and be open to the views of the people they are observing (see e.g., Flick, 2017; Pole \& Hillyard, 2016), all the while keeping track of the relations in the field, the dynamics of these relations and their own potential impact on the situations under observation. According to Katz (2019, p. 16), "ethnographers shape a research self as they work through a series of existential choices" regarding, for instance, the form of their ethnographic narrative, unexpected occurrences or difficulties and the resulting choices in the field, to name but a few factors. Further reflection on the part of the ethnographers could thus include thoughts and narratives on how their experience and interactions in the field have influenced not only the outcomes of their studies, but also their own experience of themselves as researchers and their working perspectives (for examples of such narratives in qualitative research, see, e.g., Simovska et al., 2019). 
Milošević, J., \& Risku, H. (2020). Situated cognition and the ethnographic study of translation processes: Translation scholars as outsiders, consultants and passionate participants. Linguistica Antverpiensia, New Series: Themes in Translation Studies, 19, 111-131.

\subsection{Enquirer posture}

To present and reflect on our own intended enquirer posture and the posture imposed on us by the participants in our study, but also to contrast these positions and reflect on their consequences for the course and the findings of our study, we draw on Guba and Lincoln's (2005) typology of enquirer postures in qualitative research. Our (researcher) objective was to fulfil the requirements of the constructivist research paradigm (Guba \& Lincoln, 2005) by identifying those factors that are relevant for the participants and studying the ways in which they construct meaningful action. According to Guba and Lincoln, the qualitative constructivist research paradigm views researchers as "passionate participants" (2005, p. 196) who seek to understand the object of study from the perspectives of the participants and to give them voice.

This is precisely the enquirer posture we adopted, since it corresponds to the ethnographic approach of our main research project, whose aim was to hear the voices of the participants and understand the processes of translation in modern-day real-life work settings. This position differs from other enquirer postures such as the "disinterested scientist" as an "informer of decision makers, policy makers and change agents" in the (post-)positivist paradigm or the "transformative intellectual" as an "advocate and activist" who strives to erode ignorance and misapprehensions in the critical theory paradigm (Guba \& Lincoln, 2005, p. 196).

In general, ethnographic research has a strong history of political action in which it endeavors to "help change the world in positive ways" (Denzin \& Lincoln, 2005, p. x). In our project, we sought neither to prove objective, decontextualized and generalizable knowledge in a positivist manner as "disinterested scientists" nor strategically or politically to change or improve the situations of the participants as "transformative intellectuals" or "advocates and activists" as postulated in critical theories. Instead, our objective was to obtain co-created results with a high degree of trustworthiness and authenticity as "passionate participants" (Guba \& Lincoln, 2005, p. 196).

Ethnographers should strive to obtain an insider (or emic), not an "outsider" (or etic), perspective (Pike, 1967, p. 8) and they must distance themselves from their prior expectations in order to be able to approximate the view of the situation through the eyes of the observed. To ensure that we gave precedence to the participants' voices (and not our own), we did our best to recognize our own prejudices and assumptions and reflected critically on ourselves as researchers (as described by Guba \& Lincoln, 2005). Our aim was to facilitate a multi-voice reconstruction of the observed activities - both from the insider perspective (of the various participants) and from that of the reflective researchers (i.e., ourselves; see Guba \& Lincoln, 2005).

According to Duranti (1997), ethnographers in the field of linguistic anthropology "are usually perceived as wealthy and powerful individuals who have only a temporary and in many respects very limited interest in the community they study and live in" (p. 95). However, and as was the case with our study, translation research can also be - and indeed often is - carried out by "indigenous ethnographers" (Fahim, 1982; Ohnuki-Tierney, 1984), that is, researchers who are themselves also 
Milošević, J., \& Risku, H. (2020). Situated cognition and the ethnographic study of translation processes: Translation scholars as outsiders, consultants and passionate participants. Linguistica Antverpiensia, New Series: Themes in Translation Studies, 19, 111-131.

translators. In this regard, Koskinen (2008) stresses that when "researching a familiar professional activity ... one has to be ready to question one's own interpretations and not blindly trust one's own insider knowledge" (p. 9). She had previously worked in the setting she observed (the European Union's Finnish translation department) and describes herself as "an earlier insider turned into an outsider" (2008, p. 154) - clearly recognizing the need to reflect on her own specific, changed position in relation to that of her former colleagues. In any case, ethnographers are not necessarily "child-novices" (Duranti, 1997, p. 94) or tabulae rasae in an unknown field (although they may be perceived as such by those being investigated, as one of our case studies will show).

\section{Research project description}

Before going on to describe the dynamics of the interactions between the researchers and the study participants in the field in our particular project, we would first like to present our study design and the data we collected which inspired and enabled the methodological reflection presented in this article. The primary objective of this project was to study the cognitive processes in the translation process while taking account of the technological and social embeddedness of translators and translation project managers in their real working environments. To achieve this, the research focused both on the situative cognitive processes encountered in the translation process and on the interaction between the translators and other relevant actors and artefacts in a translation project. Our ultimate aim was to improve the ecological validity of translation process research and extend its research object by investigating translation as a socio-cognitive, embodied interaction between people and artefacts.

To gain an insight and enable us to contrast the different work realities in which translation-related processes take place, we conducted workplace studies in the following four settings (cases 1 to 4 ):

(1) two freelance translators who work together on projects and proofread for each other (case 1);

(2) a translation agency with 13 project managers and two business managers (case 2);

(3) the technical documentation department in a technology company and a translation agency they work with (we did not get permission to observe or interview any of the agency's freelancers or to do the same with another translation agency the department also worked with at the time of data collection) (case 3); and

(4) the translation department in a public institution with five in-house translators (case 4).

In total, data were obtained in 58 half-day observation sessions (171 hours of observation). To increase reliability and intersubjectivity, the observations and subsequent data analysis were conducted in each case by two observers. During the observations, handwritten notes were taken to document both the work processes and the physical, technological and social environments in which they occurred. In addition to taking notes, the observers drew sketches of the rooms that formed the settings for the observations, that is, the physical environments of the workplaces observed. No video recordings were made. The participants were free to choose the observation 
Milošević, J., \& Risku, H. (2020). Situated cognition and the ethnographic study of translation processes: Translation scholars as outsiders, consultants and passionate participants. Linguistica Antverpiensia, New Series: Themes in Translation Studies, 19, 111-131.

days and the daily routines that they allowed us to observe (in one case, we were asked, for instance, not to be present in a meeting in which they were discussing a translation agency's financial situation and planning). We also conducted qualitative, semi-structured interviews (see, e.g., Flick, 2017; Gläser \& Laudel, 2010) which provided us with a total of 26 hours of interview recordings. The interviews were transcribed in line with a simplified version of the GAT conventions (Selting et al., 2011). All the data were anonymized before being subjected to a computer-assisted, qualitative content analysis (as proposed by Gläser \& Laudel, 2010) using the MAXQDA data analysis software.

\section{Relational dynamics in the field: Reactions, perceptions and expectations}

Prior to entering the field, that is, during the preparations for data collection, the members of the research team reflected on both the choice of participants and their own intended roles. Our intention was to act and be perceived by the study participants as passionate participants (Guba \& Lincoln, 2005; see above). Our preparations for the fieldwork included consulting, first, the literature on how to do and reflect on ethnography and, secondly, an anthropologist with extensive experience in field research and qualitative data analysis. This way, we worked on becoming and seeing ourselves as self-reflective facilitators of the reconstruction of situations and interactions who take the different perspectives of the various actors and participants into account. We also reflected on how we wanted the participants to perceive our research, our presence in the field and our role as researchers. We likewise tried to communicate this role as explicitly as possible when presenting our project to the potential study participants.

The goal of our overall research project was to observe the actors involved in translation-related processes and their interactions with their environments and social contexts and to analyse their perceptions and the meanings attached to them. As observers and listeners, we tried to grasp the processes and situations we were permitted to be part of. We observed excerpts from different work realities in order to capture individual perceptions and points of view, therefore collecting information on different aspects of the work situations (e.g., processes, actions, habits, tasks, perceptions, views, emotions, environment and interactions).

Nonetheless, the extent to which we were granted access to - and therefore the possibility to study - these aspects varied from case to case. To illustrate this in more detail, we now describe those aspects of the interactions between the participants and researchers which we believe accounted for the level of access granted, namely, the participants' reaction to our request to participate in the study, their perceptions of us and our role as researchers, and their expectations and desired trade-offs. We have based the descriptions presented below on both the meetings and the written correspondence with the participants prior to the data collection and their explicit statements and behaviour during data collection.

\subsection{Participants' reactions to the request to participate}


Milošević, J., \& Risku, H. (2020). Situated cognition and the ethnographic study of translation processes: Translation scholars as outsiders, consultants and passionate participants. Linguistica Antverpiensia, New Series: Themes in Translation Studies, 19, 111-131.

As the literature on ethnography shows (e.g., Flick, 2017; Pole \& Hillyard, 2016), one of the first and biggest challenges in ethnographic research is gaining access to the field. The first step in getting people to allow researchers to observe their lives and/or work realities is the presentation of the research interests and method as well as the contribution that is expected of potential participants. In hierarchical workplaces such as large enterprises and organizations, obtaining permission to observe individuals or groups of people, that is, the access to the setting and extent of the observers' presence in the field, may first have to be negotiated with decision-makers further up the hierarchy.

However, as Pole and Hillyard (2016, p. 27) rightly point out, obtaining their permission does not necessarily ensure that the participants themselves will be open-minded and cooperate wholeheartedly with the researchers. Indeed, and as we ourselves experienced in one of our cases, it could in fact transpire that some of the participants would still have reservations about certain elements of the research. In our case (see below, case 3), these reservations became evident only after we had obtained the formal consent for participation in the project, that is, once we began the data-collection period. The reservations were not expressed during the presentation of our research or in the negotiations regarding the participation, even though the people we sought to observe were all present and actively involved in these meetings.

In all four of our case studies, we presented the research project to all the potential participants in advance and gave them the opportunity to ask questions before they made a final decision on their participation. During this process, we tried to explain the aims of our study and demonstrate that our intended enquirer posture was designed to make them feel comfortable and safe in showing us authentic excerpts of their everyday work routines. Nonetheless, the reactions of the participants varied from case to case. In case 1, both freelancers quickly agreed to participate in the project. One of them had taken part in previous studies conducted by the research project lead and was therefore already familiar with the study design and the research interests. While both she and her colleague were interested and happy to participate in the study, the latter initially expressed doubt whether her "small translator life" was "interesting enough" for a project such as ours. But after a first meeting with two of the researchers to explain the project, she also gave her consent.

The translation agency in case 2 had also participated in two previous studies, so they likewise already knew and trusted the project lead. Both the management team and the translation project managers were interested in and open-minded about participation. Two of the researchers initially met with the two members of the management team and explained the main ideas behind the intended research. While they expressed their interest at this point, they considered it a prerequisite that the translation project managers themselves were also willing to participate. We were therefore invited to present the project to the whole team at the agency, who subsequently all agreed to take part. 
Milošević, J., \& Risku, H. (2020). Situated cognition and the ethnographic study of translation processes: Translation scholars as outsiders, consultants and passionate participants. Linguistica Antverpiensia, New Series: Themes in Translation Studies, 19, 111-131.

In case 3, a documentation department in a large technology company, two partner translation agencies and one freelance translator, the reactions to our proposal differed. The company itself had collaborated with the translation department at our university prior to the study, in particular by supervising Master's theses that were of interest to the company. When it came to our project, the preliminary discussions to explain the study and arrange an appointment with the technical communication team (who would be the actual participants) proved to be laborious. To the best of our knowledge, the decision to participate in the study was taken by company management, who gave us their formal consent and required us to sign a confidentiality agreement that would guarantee anonymity (which we had already proposed to do).

The company provided us with the contact details of the two translation agencies with which they regularly collaborated. Agency 1 was interested in and open to participating in the study. Its CEO had participated in a previous project conducted by one of the researchers, so she quickly agreed to do so again. In an effort to cover the full translation chain, we asked the agency if we could also interview a freelancer who works on the technology company's assignments. Unfortunately, no such contact was established. While Agency 2 initially also agreed to participate, its management team subsequently withdrew this consent, stating concerns that we might gain too much insight into their business and the current market situation, which could increase competition and lead to a potential loss of business.

In case 4, the translation department of a public-sector institution, the translators themselves were interested in and open to participating in the study from the outset. One of them already knew the project lead from events organized by the Austrian Association of Translators and was keen to hear about the research aims. In an internal meeting, the translators decided that they would like to participate and approached their line manager, who is not a translator, to request permission to do so. The final decision to participate involved multiple levels of management.

All in all, the granting of access to the setting varied greatly between the cases: some participants welcomed us actively and even convinced their line managers to give us permission to observe and interview them; others participated either voluntarily or with reluctance after their line managers had given their consent. These differences proved influential later in the project, as the following sections show.

\subsection{The participants' perceptions of the researchers}

Once ethnographers have obtained permission to enter a given setting, their relationships and interactions with the participants determine the further success of the project. As became evident in our study, these aspects depend greatly on the participants' perceptions of the researchers and the goals of the study. In multiple case study research, participants' perceptions can vary even though they are all provided with the same initial information about the project. This proved to be the case in our study. 
Milošević, J., \& Risku, H. (2020). Situated cognition and the ethnographic study of translation processes: Translation scholars as outsiders, consultants and passionate participants. Linguistica Antverpiensia, New Series: Themes in Translation Studies, 19, 111-131.

The freelancers (case 1) saw and accepted us as interested observers of the situations in which we were participating. They each allowed us five days of full access to their working environments - in both cases dedicated rooms in their homes reserved solely for work. They were both open to occasionally explaining some of their work processes and decisions in situ and answering our questions. Interestingly, they also at times even forgot we were present or referred to us as "the shadow" in a telephone conversation they had with each other while being observed. They also felt free to perform tasks that were not directly related to their work (e.g., taking the dog out, doing laundry, opening letters, etc.) during the time we were there, as they normally would in the course of a working day.

In case 2, the translation agency team welcomed us as interested observers and university lecturers but saw us more as scholars who, as such, are "remote from practice" and therefore know little about current project management processes and technology. They also saw us as "learners" and put great effort into explaining their tasks, tools and processes in detail to us. However, they did also ascribe us some power as representatives of the field of academia. This became evident when we were explicitly asked whether and to what extent our study would influence future translator training at university level - for instance, by adding more project management content to the curriculum. Further expectations were linked to the fact that we investigate cognitive aspects of translation, with one member of the team remarking in an early meeting that since we were cognitive scientists, we could tell what goes on in their heads.

Different perceptions of the researchers in case 3 resulted in different degrees of cooperation during the data-collection period. Some members of the documentation department team saw us as an academic authority and initially assumed that our ultimate interest lay in evaluating their processes, conducting a target-actual comparison and developing a model of optimal performance and processes. Before we began collecting data at his workplace, one of the technical writers again asked explicitly about the goals of the study, even though these had already been explained in detail in two previous meetings at which he had been present. We got the impression that he did not feel comfortable talking about his work processes, situation and emotions until the researcher had reassured him that evaluating these processes was definitely not a study goal. Once this reassurance had been given, the interview and observations with this particular participant produced a wealth of insights into his current work practices and made a significant contribution to the value of the research project.

Other members of the team, in contrast, felt that we - as non-practitioners - would not be able to understand the processes "live" and therefore declined to let us observe them. They chose instead to show us examples of their translation projects in retrospections, and we could sense their - not previously expressed - resistance to being observed during the first data-collection session. We naturally did not insist on participant observation in their case, and held none of the planned multiple and extended observation sessions with these participants. In fact, we visited them only once. The behaviours that indicated their lack of willingness to participate in the research included laughing at some of our questions (almost as if to ridicule them), giving fleeting 
Milošević, J., \& Risku, H. (2020). Situated cognition and the ethnographic study of translation processes: Translation scholars as outsiders, consultants and passionate participants. Linguistica Antverpiensia, New Series: Themes in Translation Studies, 19, 111-131.

responses and insisting on only being interviewed (a) once and (b) together, therefore denying the two different observers the chance to collect data at their individual workplaces and interview them separately. An analysis of the interviews with these members of the team and another technical writer at the company indicates that they were unhappy with their position in the company, did not fully agree with the way translation processes were managed and were frustrated by their own inability to change the situation. Their reluctance to participate can also be viewed in this light.

Another technical writer at this company appeared to view us as learners and went into "teacher mode" every time we visited, even going as far as to explain the history of the technology sector and the company itself. While his enthusiastic accounts of its activities provided us with valuable general information on the context, it did not ultimately serve our main goal of immersing ourselves in authentic work processes and situations.

As mentioned above, one of the technology company's translation agencies welcomed and viewed us as interested observers and translation/interpreting colleagues. This agency allowed us to observe its processes, and the participants there had no qualms about showing emotions such as fear, worry or frustration when discussing the difficulties involved in managing crisis situations with some clients. During our interview with the translation project manager, we got the impression that she appreciated someone showing an interest in her situation and listening to her talk about it, especially when it came to the cooperation with the technology company (which was not always conflict-free).

In the case of the second translation agency, whose staff were concerned about our gaining too much insight, we can only surmise that they saw us as (intended or unintended) "spies" who would be able to reveal details of their operations and therefore trigger a loss in their volume of business. However, we have no explicit evidence to back up this assumption other than the statement mentioned in the previous section.

The translation department in the public institution (case 4) welcomed us as interested scientists and experts in Translation Studies and therefore participated robustly in the study. They allowed us to observe their work and attend their meetings. They also answered our questions carefully and took time to explain thoroughly any processes we did not immediately understand. Some of their colleagues from other departments (whom we met during lunch breaks) were confused about the goal of the study and initially assumed that our aim was to identify ways of optimizing the institution's translation processes. However, this assumption was not shared by the actual participants in the translation department, who understood that we were trying to capture the complexities of translation work, including the processes, actors and technologies involved. 
Milošević, J., \& Risku, H. (2020). Situated cognition and the ethnographic study of translation processes: Translation scholars as outsiders, consultants and passionate participants. Linguistica Antverpiensia, New Series: Themes in Translation Studies, 19, 111-131.

\subsection{The participants' expectations and (desired) trade-offs}

When presenting the study to potential participants, we tried to identify their own interests and expectations in order to determine whether we could incorporate these into the study and therefore provide them with an added benefit. In all four case studies, the participants expected the data to be kept confidential. When asked if they had benefitted from participating in the study, the two freelancers in case 1 expressed their appreciation of the opportunity to reflect on their own work processes and noted that they had since become aware of certain patterns of action (some of which are described in Risku, 2014; Risku et al., 2016). They even asked if we could send them the anonymized transcriptions of the observation protocols, which was something we had already included as an option in our research plan if requested to do so by the participants. One of the freelancers told us that being observed and reading the protocols had made her aware of the amount of time she spent on social media and that she had since adapted her behaviour to make her working time more efficient and reduce the extent of such distractions during working hours.

The translation agency management team in case 2 was interested in our analysis of its project managers' level of satisfaction with their work situation. After they explicitly communicated this to us in one of our initial meetings, we included this topic in greater detail in the interviews. We were also requested to send the agency any articles or reports prior to publication and to hold a joint presentation on its project management tools and artefacts at an industry congress. As already mentioned in the previous section, both the management team and the translation project managers expressed hopes that the study would trigger changes in the Translation Studies curriculum that would give more space and visibility to translation project management and therefore increase students' familiarity with this topic and make it a more attractive career option for graduates.

The technical documentation department in case 3 asked us to send our analyses to them and expressed their desire to continue their cooperation with our department, especially with regard to the supervision of specific theses. Some of the technical writers interviewed did not seem to expect their participation to produce any value, while others simply used the opportunity to inform us, that is, the scholars, of their own views on current translation work processes. While not mentioned explicitly, we assume that the company's middle management (who originally granted us permission and access to the setting) hoped our findings would strengthen its own position in negotiations with higher management on how to manage its translation activities. The translation agency used by the company (and which participated in the study) also asked for a copy of the final analyses.

Last, but not least, the translation department team in case 4 asked the observers to provide a one-page description outlining their perceptions of the department's working environment (including both positive and negative aspects) immediately after the observation period. They also asked for a copy of the analyses and requested that the research team give a presentation (two years after the data-collection period) on the project and its findings at a domain-specific international translation conference organized by the department at regular intervals. We see 
Milošević, J., \& Risku, H. (2020). Situated cognition and the ethnographic study of translation processes: Translation scholars as outsiders, consultants and passionate participants. Linguistica Antverpiensia, New Series: Themes in Translation Studies, 19, 111-131.

this as an indication that they viewed the project as an opportunity to actively develop their own unit and processes and that they recognized the internal and external relational value of cooperating with the university, in this way confirming their role as experts in the field of translation.

\section{Conclusions}

Our analysis and subsequent reflection on the methods used revealed, among other things, that we - as scholars - had tried to treat the different cases in the same way in order to make them comparable as different work realities in which translation-related processes take place. Yet multiple factors influenced the events, including the attitudes and behaviour of the people observed, their opinions of science and research, and their levels of satisfaction with their own work situation, position and autonomy. It is therefore important that these factors and their potential manifestations are taken into account in the planning stage for ethnographic research in the translation workplace, since it is quite possible that they will also determine the dynamics in the field and the extent to which the insights gained by the researchers might be emic. Considering different reactions and possible insecurities on the part of the translators and project managers in the preparation phase can also help to improve the way in which the research is communicated to potential participants and, if necessary, to adjust the research agenda to ensure that the participants feel comfortable about contributing. These aspects also need to be considered when interpreting the results and reporting on the findings of an ethnographic study that investigates an outtake of translation processes and practices which depend greatly on the social dynamics between those involved.

As our data and description of the social dynamics presented above show, the participants perceived us - the researchers - predominantly as "others", that is, not members of their professional group. They regarded us either as powerful, knowledgeable academic authorities, translation management consultants, interested scientists, passionate participants, spies or learners, or indeed as ignorant and uninformed. These perceptions even varied in one and the same case study, where some of the participants viewed us as knowledgeable but others regarded us as uninformed. This perception of us as outsiders who are "remote from practice" had different consequences for the research process and its outcomes in the various case studies.

On the one hand, it was beneficial as it encouraged some participants to provide thorough explanations of their work processes, tools, thoughts, learning histories and sense-making to ensure we could comprehend and subsequently describe them. This also relieved us of the "temptation" to use our own experiences from translation practice or previous research to fill any potential gaps in understanding - as we might well have done despite our conscious decision to the contrary. On the other hand, the perception of us as "others" also led some participants to decline to show us their work routines and talk about their problems and difficulties because they did not trust us to understand. 
Milošević, J., \& Risku, H. (2020). Situated cognition and the ethnographic study of translation processes: Translation scholars as outsiders, consultants and passionate participants. Linguistica Antverpiensia, New Series: Themes in Translation Studies, 19, 111-131.

This outsider enquirer posture ascribed to us by the participants is not entirely independent of our own perception of them, since we, in a way, also perceived the participants as "others". We contacted and observed them because they were translation practitioners ("others") and not translation researchers ("us"), even though all members of our research team either currently also work as translators or have done so in the past. The perceptions presuppose each other. For example, we (i.e., the researchers) all have several years of prior experience as part-time freelance translators or interpreters and translation clients but no personal experience of working full-time as translators or translation project managers. In those work settings we could identify with from personal experience we were able to advance more quickly from initial observations to orientate ourselves in the field to focusing more closely on our specific research questions. Conversely, where we had no personal experience to draw on, it took us more time to gain an overview of the context and direct our observations and interviews towards our research goals.

Being perceived as an academic authority also proved controversial as it triggered different assumptions regarding the ultimate goals of our study. While some participants hoped this authority would grant us the power to introduce curricular changes, others assumed that an evaluation and optimization of what we had observed would be our ultimate scholarly goal. We also had the impression that the participants' wellbeing at the workplace was a decisive factor: the higher the pressure to perform and the stronger the perceived potential of misunderstanding, the greater the resistance to open observation, perhaps out of fear of the consequences of any "suboptimal" processes we might identify.

Trust proved to be the key aspect that determined not only the settings to which we obtained access but also the way in which the participants perceived our research method. It was this trust that subsequently also allowed a sufficiently open interaction between the ethnographers and the participants. As our data show, those participants who had already been involved in prior studies and knew at least one of the researchers accepted the research proposal quickly and even contributed actively to the research process by suggesting specific topics for inclusion in the analysis. In contrast, some of the participants who knew none of the researchers or their previous research prior to the study were less inclined to participate or even mistrusted the participant observation method. They tended to expect that the observations would produce not only detailed descriptions and a deeper understanding of their work but also an evaluation and optimization of the work(ers) observed.

The analysis of translators' work which does not merely draw on prototypical or ideal work situations but seeks instead to describe it based on data collected in authentic work situations is not yet an established research approach in Translation Studies. However, there is a growing body of research which, in addition to providing rich descriptions of translation practices, also reveals new research questions that could be addressed in future workplace studies. Longitudinal studies in particular will enable a long-term investigation of the changes in the dynamics in the field. 
Milošević, J., \& Risku, H. (2020). Situated cognition and the ethnographic study of translation processes: Translation scholars as outsiders, consultants and passionate participants. Linguistica Antverpiensia, New Series: Themes in Translation Studies, 19, 111-131.

Fostering the links between translation scholars and practitioners is crucial to obtaining access to such authentic settings: doing so will help to overcome some of the methodological challenges of ethnographic research in Translation Studies and will also be beneficial to the translation industry and academia alike (see Risku et al., 2020). Making research(ers') motivation and rationale more visible for practitioners (i.e., potential study participants) would strengthen the trust that is necessary for them to allow researchers to observe their work and decision-making processes and to reveal their thoughts, feelings and actions. Being informed about the current processes and translation-related projects in the industry - for instance, through visits by practitioners and researchers to industry and academic conferences, (in)formal meetings or newsletters and technical journals - can help researchers to keep abreast of current developments and, if they obtain access, enable them to observe processes from the very beginning as they are being implemented in and adjusted to their particular environment. In an ideal scenario, stronger links and exchanges between academia and the industry might also result in the development of a common research agenda that combines the interests of both researchers and practitioners alike.

\section{References}

Abdallah, K. (2011). Quality problems in AVT production networks: Reconstructing an actor-network in the subtitling industry. In A. Şerban, A. Matamala, \& J.-M. Lavaur (Eds.), Audiovisual translation in close-up: Practical and theoretical approaches (pp. 173-186). Peter Lang.

Agre, P. E., \& Chapman, D. (1991). What are plans for? In P. Maes (Ed.), Designing autonomous agents: Theory and practice from biology to engineering and back (pp. 17-34). MIT Press.

Angelone, E., Ehrensberger-Dow, M., \& Massey, G. (2016). Cognitive processes. In C. V. Angelelli \& B. J. Baer (Eds.), Researching translation and interpreting (pp. 43-57). Routledge. https://doi.org/10. $\underline{4324 / 9781315707280}$

Asare, E. K. (2011). An ethnographic study of the use of translation tools in a translation agency: Implications for translation tool design [Unpublished doctoral dissertation]. Kent State University.

Borg, C. (2017). A literary translation in the making: An in-depth investigation into the process of a literary translation from French into Maltese [Unpublished doctoral dissertation]. Aston University.

Brannan, M., Pearson, G., \& Worthington, F. (2007). Ethnographies of work and the work of ethnography. Ethnography, 8(4), 395-402. https://doi.org/10.1177/1466138107083558

Brooks, R. A. (1991). Intelligence Without Reason. In Mylopoulos J. \& R. Reiter (Eds.), Proceedings of 12th International Joint Conference on Artificial Intelligence (pp. 569-595). Sydney: Morgan Kaufmann.

Buzelin, H. (2006). Independent publisher in the networks of translation. TTR: Traduction, Terminologie, Rédaction, 19(1), 135-173. https://doi.org/10.7202/016663ar

Buzelin, H. (2007). Translations "in the making." In M. Wolf \& A. Fukari (Eds.), Constructing a sociology of translation (pp. 135-169). John Benjamins. https://doi.org/10.1075/btl.74.11buz

Christensen, T. P. (2011). Studies on the mental processes in translation memory-assisted translation: The state of the art. Trans-kom, 4(2), 137-160.

Clark, A. (1996). Being there: Putting brain, body and world together again. The MIT Press. https://doi. org/10.7551/mitpress/1552.001.0001 
Milošević, J., \& Risku, H. (2020). Situated cognition and the ethnographic study of translation processes: Translation scholars as outsiders, consultants and passionate participants. Linguistica Antverpiensia, New Series: Themes in Translation Studies, 19, 111-131.

Delamont, S., \& Atkinson, P. (2018). The ethics of ethnography. In R. Iphofen \& M. Tolich (Eds.), The SAGE handbook of qualitative research ethics (pp. 119-132). SAGE. https://doi.org/10.4135/97815264354 $\underline{46}$

Denzin, N. K., \& Lincoln, Y. S. (2005). Preface. In N. K. Denzin \& Y. S. Lincoln (Eds.), The SAGE Handbook of qualitative research (3rd ed., pp. ix-xix). SAGE.

Duflou, V. (2016). Be(com)ing a conference interpreter: An ethnography of EU interpreters as a professional ommunity. John Benjamins. https://doi.org/10.1075/btl.124

Duranti, A. (1997). Linguistic anthropology. Cambridge University Press. https://doi.org/10.1017/ CBO9780511810190

Ehrensberger-Dow, M. (2014). Challenges of translation process research at the workplace. MonTI Special Issue-Minding Translation, 7(Special Issue 1), 355-383. https://doi.org/10.6035/MonTI.2014.ne1.12

Ehrensberger-Dow, M., \& Hunziker Heeb, A. (2016). Investigating the ergonomics of a technologized translation workplace. In R. Muñoz Martín (Ed.), Reembedding translation process research (pp. 6987). John Benjamins. https://doi.org/10.1075/btl.128.04ehr

Ehrensberger-Dow, M., \& Massey, G. (2019). Socio-technical issues in professional translation practice. In H. Risku, R. Rogl, \& J. Milošević (Eds.), Translation practice in the field: Current research on sociocognitive processes (pp. 105-122). John Benjamins. https://doi.org/10.1075/bct.105.06ehr

Emerson R. M., Fretz R. I., \& Shaw L. L. (1995). Writing ethnographic fieldnotes. University of Chicago Press. https://doi.org/10.7208/chicago/9780226206851.001.0001

Emerson, R. M., Fretz, R. I., \& Shaw, L. L. (2007). Participant observation and fieldnotes. In P. Atkinson, A. Coffey, S. Delamont, J. Lofland, \& L. Lofland (Eds.), Handbook of ethnography (pp. 352-368). SAGE. http://dx.doi.org/10.4135/9781848608337.n24

Eriksson, P., Henttonen, E., \& Meriläinen, S. (2012). Ethnographic field notes and reflexivity. In L. Naidoo (Ed.), An ethnography of global landscapes and corridors (pp. 9-22). InTechOpen. https://doi.org/ $10.5772 / 36039$

Fahim, H. (1982). Indigenous anthropology in non-western countries. Carolina Academic Press.

Fetterman, D. M. (2010). Ethnography: Step-by-step. SAGE.

Fine, G. A. (2010). Ten lies of ethnography: Moral dilemmas of field research. In P. Atkinson \& S. Delamont (Eds.), SAGE qualitative research methods (pp. 251-272). SAGE. https://doi.org/10.4135/97808570 $\underline{28211}$

Flick, U. (2017). Qualitative Sozialforschung: Eine Einführung (8th ed.). Rowohlt.

Flynn, P. (2004). Skopos theory: An ethnographic enquiry. Perspectives: Studies in Translation Theory and Practice, 12(4), 270-285. https://doi.org/10.1080/0907676X.2004.9961507

Gläser, J., \& Laudel, G. (2010). Experteninterviews und qualitative Inhaltsanalyse: Als Instrumente rekonstruierender Untersuchungen. Verlag für Sozialwissenschaften. https://doi.org/10.1007/978-3$\underline{531-91538-8}$

Gold, R. L. (1958). Roles in sociological field observation. Social Forces, 36(3), 217-223. https://doi.org/10. $\underline{2307 / 2573808}$

Guba, E. G., \& Lincoln, Y. S. (2005). Paradigmatic controversies, contradictions, and emerging confluences. In N. K. Denzin \& Y. S. Lincoln (Eds.), The SAGE handbook of qualitative research (3rd ed.,pp. 191-215). SAGE.

Hakola, M. (2007). Tekstien tanssi: Intertekstuaalisuuden kääntäminen Michael Kunzen musikaalilibretossa Tanz der Vampire [Unpublished master's thesis]. University of Tampere. https://tampub.uta.fi/bitstream/handle/10024/78481/gradu02174.pdf 
Milošević, J., \& Risku, H. (2020). Situated cognition and the ethnographic study of translation processes: Translation scholars as outsiders, consultants and passionate participants. Linguistica Antverpiensia, New Series: Themes in Translation Studies, 19, 111-131.

Halverson, S. L., \& Muñoz Martín, R. (2020). The times, they are a'changin: Multilingual mediated communication and cognition. In R. Munõz Martín \& S. L. Halverson (Eds.), Multilingual mediated communication and cognition (IATIS Yearbook series). Routledge.

Heath, C., Knoblauch, H., \& Luff, P. (2000). Technology and social interaction: The emergence of 'workplace studies'. The British Journal of Sociology, 51(2), 299-320. https://doi.org/10.1080/000713 10050030190

Hokkanen, S. (2013). Tulkki keskellä hengellistä kokemusta: Simultaanitulkkaus Tampereen helluntaiseurakunnan kokouksessa. In K. Koskinen (Ed.), Tulkattu Tampere (pp. 273-294). Tampere University Press.

Hubscher-Davidson, S. (2011). A discussion of ethnographic research methods and their relevance for translation process research. Across Languages and Cultures, 12(1), 1-18. https://doi.org/10.1556/ Acr.12.2011.1.1

Iphofen, R. (2013). Research ethics in ethnography/anthropology. DG Research and Innovation, European Commission. https://ec.europa.eu/research/participants/data/ref/h2020/other/hi/ethics-guideethnog-anthrop en.pdf

Jakobsen, A. L. (2017). Translation process research. In J. W. Schwieter \& A. Ferreira (Eds.), The handbook of translation and cognition (pp. 21-49). Wiley-Blackwell. https://doi.org/10.1002/9781119241485.ch2

Kastberg, P. (2009). Zur Ontogenese einer Instruktion: Erarbeitung eines Methodengerüsts und erste Erfahrungen. In M. G. Ditlevsen, P. Kastberg, \& C. Andersen (Eds.), Sind Gebrauchsanleitungen zu gebrauchen?: Linguistische und kommunikativ pragmatische Studien zu skandinavischen und deutschen Instruktionstexten (Europäische Studien zur Textlinguistik, 6, pp. 38-68). Narr.

Katz, J. (2019). On becoming an ethnographer. Journal of Contemporary Ethnography, 48(1), 16-50. https://doi.org/10.1177/0891241618777801

Kinnunen, T. (2010). Agency, activity and court interpreting. In T. Kinnunen \& K. Koskinen (Eds.), Translators' agency (pp. 126-164). Tampere Studies in Language, Translation and Culture, Series B 4. Tampere University Press.

Knoblauch, H., \& Heath, C. (2006). Die Workplace Studies. In W. Rammert \& C. Schubert (Eds.), Technografie. Zur Mikrosoziologie der Technik (pp. 141-161). Campus.

Kolb, W. (2011). The making of literary translations: Repetition and ambiguity in a short story by Ernest Hemingway. Across Languages and Cultures, 12(2), 259-274. https://doi.org/10.1556/Acr.12.2011. $\underline{2.7}$

Koskinen, K. (2008). Translating institutions: An ethnographic study of EU translation. Routledge. https://doi.org/10.4324/9781315759760

Kuznik, A., \& Verd, J. M. (2010). Investigating real work situations in translation agencies: Work content and its components. Hermes, 44, 25-43. https://doi.org/10.7146/hjlcb.v23i44.97263

LeBlanc, M. (2013). Translators on translation memory (TM): Results of an ethnographic study in three translation services and agencies. Translation and Interpreting Studies, 5(2), 1-13. https://doi.org/10.12807/ti.105202.2013.a01

Marinetti, C., \& Rose, M. (2013). Process, practice and landscapes of reception: An ethnographic study of theatre translation. Translation Studies, 6(2), 166-182. https://doi.org/10.1080/14781700.2013. $\underline{777258}$

Massey, G., \& Ehrensberger-Dow, M. (2011). Technical and instrumental competence in the translator's workplace: Using process research to identify educational and ergonomic needs. ILCEA Revue, 14, 114. https://doi.org/10.4000/ilcea.1060 
Milošević, J., \& Risku, H. (2020). Situated cognition and the ethnographic study of translation processes: Translation scholars as outsiders, consultants and passionate participants. Linguistica Antverpiensia, New Series: Themes in Translation Studies, 19, 111-131.

Meyer, C. (2013). Ethnography: Body, communication and cultural practices. In C. Müller, A. Cienki, E. Fricke, S. H. Ladewig, D. McNeill, \& S. Tessendorf (Eds.), Body-Language-Communication: An international handbook on multimodality in human interaction (pp. 227-239). De Gruyter Mouton. https://doi.org/10.1515/9783110261318.227

Mullamaa, K. (2006). Towards a dynamic role conception of liaison interpreters: An ethnographic study of self-descriptions of practicing liaison interpreters in Estonia. Dissertationes Philologiae Anglicae Universitatis Tartuensis 1. Tartu University Press.

Muñoz Martín, R. (2010) Leave no stone unturned: On the development of cognitive translatology. Translation and Interpreting Studies, 5(2), 145-162. https://doi.org/10.1075/tis.5.2.01mun

Muñoz Martín, R. (2016) Reembedding translation process research: An introduction. In R. Muñoz Martín (Ed.), Reembedding trans/ation process research (pp. 1-20). John Benjamins. https://doi.org/10. $\underline{1075 / \mathrm{btl} .128 .01 \mathrm{mun}}$

Muñoz Martín, R. (2017). Looking toward the future of Cognitive Translation Studies. In J. W. Schwieter \& A. Ferreira (Eds.), The handbook of translation and cognition (pp. 555-571). Wiley-Blackwell. https:// doi.org/10.1002/9781119241485.ch30

Murphy, E., \& Dingwall, R. (2007). The ethics of ethnography. In P. Atkinson, A. Coffey, S. Delamont, J. Lofland, \& L. Lofland (Eds.), Handbook of ethnography (pp. 339-351). SAGE. https://doi.org/10.4135/ $\underline{9781848608337 . n 23}$

Ohnuki-Tierney, E. (1984). Native anthropologists. American Ethnologist, 11(3), 584-586. https://doi.org/ 10.1525/ae.1984.11.3.02a00110

Olohan, M. (2019). Knowing in translation practice: A practice-theoretical perspective. In H. Risku, R. Rogl, \& J. Milosevic (Eds.), Translation practice in the field: Current research on socio-cognitive processes (pp. 161-182). John Benjamins. https://doi.org/10.1075/bct.105.08olo

Olohan, M., \& Davitti, E. (2017). Dynamics of trusting in translation project management: Leaps of faith and balancing acts. Journal of Contemporary Ethnography, 46(4), 391-416. https://doi.org/10.1177/ $\underline{0891241615603449}$

Pike, K. L. (1967). Language in relation to a unified theory of structure of human behavior (2nd ed.). Mouton. https://doi.org/10.1037/14786-000

Pole, C., \& Hillyard, S. (2016). Doing fieldwork. SAGE. https://doi.org/10.4135/9781473966383

Risku, H. (2014). Translation process research as interaction research: From mental to socio-cognitive processes. MonTI. Monografías De Traducción E Interpretación, 2014(1), 331-353. https://doi.org/ 10.6035/MonTI.2014.ne1.11

Risku, H. (2016). Translationsmanagement: Interkulturelle Fachkommunikation im Informationszeitalter (3rd ed.). Narr.

Risku, H. (2017). Ethnographies of translation and situated cognition. In J. W. Schwieter \& A. Ferreira (Eds.), The handbook of translation and cognition (pp. 290-310). Wiley-Blackwell. https://doi.org/10.1002/ 9781119241485.ch16

Risku, H., Hirvonen, M., Rogl, R., \& Milošević, J. (forthcoming). Ethnographic research. In F. Zanettin \& C. Rundle (Eds.), The Routledge handbook of translation and methodology. Routledge.

Risku, H., Milošević, J., \& Pein-Weber, C. (2016). Writing vs. translating: Dimensions of text production in comparison. In R. Muñoz Martín (Ed.), Reembedding translation process research (pp. 47-68). John Benjamins. https://doi.org/10.1075/btl.128.03ris

Risku, H., Rogl R., \& Milošević, J. (2019). Translation research in the field: Current research on sociocognitive processes. In H. Risku, R. Rogl, \& J. Milošević (Eds.), Translation practice in the field: Current 
Milošević, J., \& Risku, H. (2020). Situated cognition and the ethnographic study of translation processes: Translation scholars as outsiders, consultants and passionate participants. Linguistica Antverpiensia, New Series: Themes in Translation Studies, 19, 111-131.

research on socio-cognitive processes (pp. 1-24). John Benjamins. https://doi.org/10.1075/bct.105. $\underline{01 \text { ris }}$

Risku, H., Rogl, R., \& Milošević, J. (2020). Researching workplaces. In E. Angelone, M. Ehrensberger-Dow, \& G. Massey (Eds.), The Bloomsbury companion to language industry studies (pp. 37-62). Bloomsbury Publishing. https://doi.org/10.5040/9781350024960.0007

Risku, H., \& Windhager, F. (2015). Extended translation: A sociocognitive research agenda. In M. Ehrensberger-Dow, S. Göpferich, \& S. O'Brien (Eds.), Interdisciplinarity in translation and interpreting process research (pp. 35-47). John Benjamins. https://doi.org/10.1075/bct.72.04ris

Robben, A. C. G. M., \& Sluka, J. A. (2015). Ethnography. In J. D. Wright. (Ed.), International encyclopedia of the social \& behavioral sciences (2nd ed., pp. 178-183). Elsevier. https://doi.org/10.1016/B978-0-08097086-8.12065-3

Selting, M., Auer, P., Barden, B., Bergmann, B., Couper-Kuhlen, E., Günther, S., Meier, C., Quasthoff, U., Schlobinski, P., \& Uhmann, S. (2011). A system for transcribing talk-in-interaction: GAT 2 (Translated and adapted for English by E. Couper-Kuhlen \& D. Barth-Weingarten). Gesprächsforschung - Online Zeitschrift zur verbalen Interaktion, 12, 1-51.

Shapiro, L. A. (2019). Embodied cognition (2nd ed.). Routledge. https://doi.org/10.4324/9781315180380

Simmons, M. (2007). Insider ethnography: Tinker, tailor, researcher or spy? Nurse Researcher, 14(4), 714. https://doi.org/10.7748/nr2007.07.14.4.7.c6039

Simovska, V., Colding Lagermann, L., Salah A. H., Lerche M. L., \& Kousholt, D. (2019). Inside out: What we (don't) talk about when we talk about research. Qualitative Research, 19(2), 113-130. https://doi. org/10.1177/1468794117749165

Smith, V. (2007). Ethnographies of work and the work of ethnographers. In P. Atkinson, A. Coffey, S. Delamont, J. Lofland, \& L. Lofland (Eds.), Handbook of ethnography (pp. 220-231). SAGE. https://doi. org/10.4135/9781848608337.n15

Suchman, L. (2007). Human machine configurations: Plans and situated actions (2nd ed.). Cambridge University Press. https://doi.org/10.1017/cbo9780511808418.008

Sun, S. (2014). Rethinking translation studies. Translation Spaces, 3(1), 167-191. https://doi.org/10.1075/ $\underline{\text { ts.3.08sun }}$

Thelen, E., \& Smith, L. B. (1994). A dynamic systems approach to the development of cognition and action. The MIT Press.

Walter, S. (2014). Kognition. Reclam.

Wilson, M. (2002). Six views of embodied cognition. Psychonomic Bulletin \& Review, 9(4), 625-636. https://doi.org/10.3758/BF03196322

1 For a typology based on different degrees of involvement on the part of the observer, see, e.g., Gold (1958). This topic is also discussed in Flick (2017). 